\title{
DIALOG INSEKURITAS PANGAN BERDASARKAN KAJIAN KEAMANAN INTERNASIONAL: GUGATAN PENDEKATAN KRITIS TERHADAP PENDEKATAN ARUS-UTAMA
}

\author{
Aspin Nur Arifin Rivai \\ Universitas Islam Negeri Alauddin \\ Email: askaspin@gmail.com
}

\begin{abstract}
ABSTRAK
Artikel ini merupakan studi pustaka teoretis dalam mengeksplorasi berbagai perspektif tentang insekuritas pangan. Penulis memusatkan perhatian pada diskusi insekuritas pangan, berupa kelaparan yang dianggap memiliki beberapa limitasi pandangan. Diskursus ketahanan pangan dan kedaulatan pangan saling bertentangan. Meski begitu, keduanya bukan sebagai konsep yang saling bertentangan, melainkan sebagai konsep yang saling terkait, terutama mencakup upaya penanggulangan kelaparan yang meliputi akses, distribusi, keamanan dan kesetaraan. Sedangkan pendekatan keamanan nasional yang berbasis realisme dan human security berdasarkan Copenhagen School memiliki perbedaan yang cukup signifikan. Namun, keduanya memiliki limitas dalam memposisikan kelaparan sebagai masalah keamanan. Realisme yang bertumpu pada tempat-tempat yang berpusat pada negara menangani kelaparan adalah konsentrasi kegiatan pemerintah dalam menjamin kepentingan nasional, sehingga kebijakan yang ada adalah bagaimana ketersediaan atau surplus pangan dapat dipenuhi. Selanjutnya perspektif human security melihat pada masalah kelaparan yang dihadapi manusia sehingga diperlukan proses sekuritisasi yang dilakukan oleh agen. Di sini terlihat bahwa tindakan untuk mengatasi masalah fundamental hanya menjadi tanggung jawab elit pemerintah, sedangkan suara kepentingan individu yang mengalami kelaparan terabaikan. Dengan demikian, pendekatan keamanan kritis muncul dalam menengahi beragam limitasi di atas. Isu kelaparan harus mengalami pembingkaian ulang baik secara definisi maupun dalam aplikasi kebijakan sebagaimana masalah keamanan ini sebagai masalah structural.
\end{abstract}

Kata Kunci: Kerawanan Pangan, Kelaparan, Keamanan Pangan, Kedaulatan Pangan, dan Kritik Keamanan

\begin{abstract}
This article is a theoretical review based on idea comparisons in exploring various perspectives on food insecurity. Overall, the authors focus on the discussion of food insecurity, in the form of hunger which is considered to have several limitations. The narrative or discursive of food security and food sovereignty contradicts one another. Even so, the two are not as oppositional concepts, but as interrelated concepts, especially covering efforts to overcome hunger which includes access, distribution, security and equality. Meanwhile, the approach to national security based on realism and human security based on the Copenhagen School has significant differences. However, both have problems in positioning hunger as a security issue. Realism that relies on the state-centric places dealing with hunger is the concentration of government activities in ensuring national interests, so that the existing policies are on how the food availability can be fulfilled or surplus. Subsequently, the human security perspective looks at the hunger issue faced by humans so that a securitization process is needed that is carried out by securitization agency. It can be seen here that actions to overcome fundamental problems are only the responsibility of the elite governments, while the voices of the interests of individuals experiencing hunger are neglected. Thus, a critical security approach appears to mediate the above limitations. This perspective offers that the issue of hunger should be reframed as this security problem is a structural problem. Furthermore, this approach proposes the definition of food security in vulnerable populations from the structural violence of hunger.
\end{abstract}

Key Words: Food Insecurity, Hunger, Food Security, Food Soverignty, Critical Security

\section{PENDAHULUAN}


Insekuritas pangan adalah salah satu dari sekian isu yang memiliki probabilitas mengganggu situasi damai, sehingga isu ini dianggap relevan dalam tataran praktis maupun perdebatan ontologis dalam studi keamanan internasional. Isu ini juga kerapkali diklasifikasikan sebagai isu keamanan non-tradisional. Secara konseptualisasi, perbincangan insekuritas pangan juga diposisikan sebagai bagian dari wujud keamanan non-tradisional yang relevan hari ini. Ini didasari oleh sifatnya yang dapat menciptakan distabilitas ke berbagai dimensi, dan bergerak secara transnasional. Guna menyoal isu ketahanan pangan, pada dasarnya memang memiliki beragam sudut pandang yang bergantung pada sisi mana kita sedang amati. Salah satunya, menjelaskan mengapa harga pangan kian melonjak sementara petani yang menghasilkan produk pangan justru berpotensi mengalami kelaparan.

Laporan World Food Programme menunujukkan permasalahan kelaparan merupakan risiko kesehatan utama yang membunuh manusia yang lebih banyak dibandingkan dengan penyakit pandemik, AIDS (Acquired Immune Deficiency Syndrome) dan TBC (Tuberculosis), sehingga kelaparan menjadi ancaman eksistensial. Pada tahun 2009, terdapat lebih dari satu miliar orang yang menderita kelaparan kronis di seluruh dunia - yang jumlahnya semakin bertambah besar sejak krisis pangan dunia pada dekade 1970an (Death, 2011). Di beragam data lain juga hampir bersepakat bahwa isu ketahanan pangan kerap menjadi momok dan sumber insekuritas pada level global, regional hingga individual yang telah berlangsung dalam beberapa dekade terakhir.

Akan tetapi, dalam sisi perdebatan keamanan internasional, isu ini kerap dianalisis dalam bayang politik maupun ekonomi. Dengan demikian, fokus penanganan kebijakan hanya menyentuh faktor determinasi semata. Sementara itu, pengamatan yang berusaha mendudukkan ulang tentang apa sebenaranya insekuritas pangan itu, lantas mengapa dan bagaimana sudut pandang studi keamanan bisa menyodorkan tawaran yang jauh lebih reflektif dan kritis kurang mendapat tempat. Padahal isu ketahanan pangan pada dasarnya tidak melulu berbicara soal naik turunnya harga pangan, ataupun rantai ekonomi global. Bayang-bayang ancaman sesungguhnya adalah mereka yang mengalami kelaparan. Aspek kelaparan inilah yang menjadi gerbang perdebatan tulisan ini, bahwa keamanan nontradisional yang jauh lebih kritis adalah memusatkan pada gugatan terhadap pendekatanpendekatan arus utama yang tergolong mensimplifikasi persoalan. Pada titik ini, penulis mengamati ada beragam persoalan muncul baik pada level teoretis maupun praktis terkait 
konsep insekuritas pangan. Dengan demikian, tulisan ini menawarkan sudut pandang baru, bahwa insekuritas pangan yang pada khususnya mengacu kelaparan dapat dilihat dalam pendekatan keamanan kritis.

Jantung perdebatan tulisan ini ialah isu pangan dan persoalannya berkonsekuensi memperluas cakupan kajian keamanan. Untuk tujuan analisis, tulisan ini dipisahkan dalam tiga pembahasan inti. Bagian pertama menguraikan evolusi definisi ketahanan pangan yang pada gilirannya menciptakan beragam limitasi sekaligus mengivitasi para pengkritiknya mengajukan gugatan konseptual dan praktis. Bagian kedua memaparkan bagaimana wacana alternatif berupa kedaulatan pangan sebagai cara terdepan dalam mengatasi isu ketahanan pangan. Bagian ketiga memuat tentang upaya studi keamanan internasional masuk dalam debat ketahanan pangan, yakni Neorealis dan Keamanan Manusia. Bagian terakhir, menunjukkan gugatan perspektif Keamanan Kritis terhadap keseluruhan diktum-diktum pendekatan arus-utama yang dianggap nihil dan gagap memosisikan isu ketahanan pangan, khususnya berbicara kelaparan.

\section{KERANGKA ANALISIS DAN METODE PENELITIAN}

Tulisan ini pada dasarnya berangkat dengan tujuan untuk mengetahui debat-debat apa saja yang tersaji dalam perbincangan ketahanan pangan. Selanjutnya, berupaya untuk membongkar permasalahan atau limitasi perspektif arus-utama yang terkandung di dalam narasi insekuritas pangan. Dengan memproblematisasi narasi ataupun bangunan argumentasi dari pemikiran arus-utama maka penulis menggunakan metode studi pustaka teoretis.

Jenis ini merupakan kajian khusus di mana argumen-argumen teoretis, asumsiasumsi, konsistensi logis, hingga kekuatan penjelasnya berupaya dikomparasi. Tema analisis yang berupaya diamati dalam tinjauan di sini adalah mengungkap masalah kelaparan yang selama ini bersemayam dalam isu insekuritas pangan. Dalam tinjauan literatur, cara paling efektif untuk melaksanakan uji komparasi adalah mengklasifikasikan literatur berdasarkan tipologi. Tipologi yang penulis gunakan di sini berdasarkan dengan perspektif yang berbicara atau menawarkan definisi insekuritas pangan berdasarkan perspektif yang telah tersedia dalam tradisi keamanan internasional ataupun hubungan internasional.

Mereka adalah perspektif ketahanan pangan, kedaulatan pangan, keamanan nasional, keamanan manusia, dan keamanan kritis yang masing-masing menawarkan 
definisi, asumsi utama dan rekomendasi kebijakan yang satu sama lain berbeda. Perbedaan itu dilandasi oleh kerangka pikir dalam melihat isu insekuritas sekaligus juga bersandar pada tujuan-tujuan yang hendak digapai dalam memosisikan pangan itu sendiri. Topik perhatian dalam memetakan dan mengomparasi gagasan ini dilalui dengan mengamati sejauh mana mereka berbicara isu esensial dari insekuritas pangan, yakni kelaparan.

Dengan demikian, tulisan ini hendak menawarkan tinjauan spesifik dalam menyoal realitas kelaparan sebagai isu keamanan. Topik ini berposisi sebagai kerangka konsep yang akan menjembatani penulis meninjau sisi apa saja yang ditawarkan oleh berbagai perspektif keamanan, sekaligus melihat limitasi-limitasi mereka.

Istilah kelaparan kerap terasosiasikan ke dalam definisi ketahanan pangan. Awal mula kemunculan ketahanan pangan didasari oleh eksplanasi bagaimana dan mengapa orang mengalami hal tersebut. Seorang ahli developmentalis terkemuka, yakni Amartya Sen (1981) mengajukan definisi kelaparan sebagai karakteristik yang dihadapi oleh banyak orang ataupun individu yang tidak memiliki kecekupan sumber makanan untuk dikonsumsi. Padahal, alam bumi ini diproyeksikan dapat menghasilkan sumber makanan yang dapat memberi makan kepada 7.082.197.646 orang yang menghuninya. Tetapi, masih banyak orang yang mengalami kelaparan tiap harinya. Setidaknya ada 690 juta orang kelaparan. Insekuritas pangan yang akut ini telah memengaruhi sekitar 135 juta orang di 55 negara pada tahun 2019. Lebih menyedihkan lagi, jumlah itu hampir sebanding dengan penderita malnutrisi (WFP, 2021). Fenomena kelaparan juga ditandai sebagai wujud dari keberlangsungan era krisis pangan. Meminjam pandangan Balaam dan Veseth (2014) bahwa kelaparan dan krisis pangan telah eksis sebagai isu global. Namun, pada realitasnya isu ini justru lebih banyak dilanda oleh negara berkembang dan miskin. Demikian pula menurut analisis Anna Dickson (1997) bahwa kelaparan sejatinya sebagai kondisi di mana tidak hanya berada pada era krisis pangan, tetapi juga kelaparan yang berkelanjutan telah senantiasa menjadi fenomena kompleks dalam tataran global. Dalam memfokuskan perhatian pada isu kelaparan sebagai isu kompleks keamanan, sebenarnya dalam tradisi studi HI telah menawarkan beragam kerangka sebagai cara memposisikan isu kelaparan sebagai objek perhatiannya. Misalnya, liberalisme, realisme dan strukturalisme.

Perspektif liberalisme menyebut negara dapat keluar dari jerat persoalan ini apabila mengikuti seluruh program-program pembangunan moderenisme, seperti structural adjustment programme, dan juga memosisikan isu ini bisa bergerak maju menjadi high- 
politics. Kebijakan primadona dari persepektif ini berkutat pada revitalisasi denyut perdagangan dan asistensi pembangunban.

Perspektif realis bertahan pada diktum dasarnya bahwa sistem internasional yang anarki menjadikan setiap negara melakukan survivalitas (self-help system) dengan saling berkompetisi memperebutkan kekuasaan dan kekayaan guna mencapai keamanan relatif mereka. Peran negara secara esensial harus mengatur pasar nasional dan internasional sebagai wujud dari kepentingan nasional. Negara dengan kapasitas yang mampu menghasilkan surplus pertanian, kerap kali mendapatkan keuntungan dari mekanisme ketergantungan negara lain. Dengan demikian, sumber pangan yang melimpah akan menjadi senjata ampuh yang dimiliki oleh negara. Perspektif ini tidak melihat isu kelaparan sebagai tanggung-jawab moral universal. Tindakan negara yang mengutamakan moralitas universal di atas kepentingan nasional menurut Hans Morgenthau (1948) adalah kebodohan politik (political folly). Sebab, moralitas nasionalitas sarat dengan kepentingan jangka pendek, sementara moralitas universal adalah nihilisme yang kerap ditawarkan oleh penganut liberalisme. Dengan demikian, realisme menekankan bahwa isu kelaparan sepatutnya diatasi dengan melibatkan peran esensial setiap negara, sementara negara yang menghadapi masalah itu bukan menjadi tanggung-jawab bagi banyak negara. Ini didasari oleh premis self-help system.

Sementara itu, perspektif strukturalis menilai bahwa kelaparan berkorelasi positif dengan kemiskinan dan ketimpangan antara negara maju (core) dengan negara berkembang atau negara dunia ketiga (periphery) dengan karakter eksploitatif. Negara inti terus melanggenkan dominasi mereka ke negara pinggiran dengan beragam modus kuasa. Pola ini lantas menciptakan ketergantungan antara negara berkembang ke negara maju dalam beragam komoditas pangan guna mengembangkan perekonomian mereka. Artinya, kelaparan bukanlah akibat dari ketidakcukupan sumber makanan, melainkan kemisikinan yang terus diciptakan oleh negara maju ke negara berkembang melalui sistem kapitalisme. Struktur ini tertanam bukan hanya melalui rezim kapitalisme global tetapi merayap masuk ke dalam struktur terkecil suatu komunitas masyarakat dalam level domestik.

\section{PEMBAHASAN}




\section{Definisi Ketahanan Pangan: Tinjauan Historis}

Diskursus atau wacana ketahanan pangan pertama kali muncul tahun 1970-an yang berasal dari institusi pembangunan dan kebijakan internasional. Lebih tepatnya tertuang dalam dokumen Konferensi Pangan Dunia (KPD) tahun 1975. KPD mendefenisikannya sebagai ketersediaan makanan dari waktu ke waktu yang memadai bagi kebutuhan pokok manusia, mempertahankan dari ekspansi kebutuhan manusia yang semakin meningkat yang diiringi dengan meningkatnya kuantitas populasi manusia, dan mengimbangi fluktualisasi harga dan produksi pangan baik di tingkat domestik maupun global (Maxwell, 2001).

Harus diakui saat membuka secara lebar diskursus ketahanan pangan maka perbincangan yang terjadi adalah permainan ekonomi politik internasional. Saat Uni Soviet mengimpor 28 juta ton serealia (grain) dari Amerika Serikat, kemudian mengakibatkan penarikan ketersediaan sereal dunia. Dunia lantas mengalami kenaikan harga pangan (Morgan, 1979). Henry Kissinger yang merupakan Menteri Luar Negeri AS mendorong persoalan tersebut harus dibicarakan dalam agenda internasional yang dikenal sebagai KPD yang berlangsung di Roma. Kissinger menegaskan tiga hal mendasar, yakni (1) keperluan peningkatan produksi serealia; (2) membangun sumber cadangan makanan; dan (3) setiap negara harus secara aktif mengalihkan makanan dari wilayah surplus ke wilayah defisit makanan (Riley, 2017).

Secara garis besar bahwa defisit pangan yang dialami beberapa negara akibat ketiadaan dukungan teknologi dan inovasi pangan. Dengan demikian, negara yang memiliki kemampuan teknologi tersebut harus menghasilkan lebih banyak produksi yang tidak sekedar untuk urusan konsumsi domestik semata, melainkan mengekspor pangan secara massif ke negara-negara yang mengalami defisit pangan (chronic deficit countries). Penulis menilai tindakan yang digalakkan oleh Kissinger menyiratkan bahwa ketahanan pangan adalah narasi tentang akses teknologi dan inovasi, konteks georafi, dan ketimpangan. Kondisi ini lantas menunjukkan bahwa AS dan Uni Eropa yang seolah-olah menjadi fasilitator pangan dunia.

Akar insekuritas pangan adalah kelaparan dan kenaikan harga pangan dunia, sehingga sekelompok negara yang memiliki kemajuan tekonologi dan inovasi menawarkan jalan keluar dari persoalan tersbut. Istilah tersebut dituangkan dalam diskursus moderenisasi pertanian, yakni penyebaran teknologi Revolusi Hijau (Green Revolution). Ide ini kemudian secara praktis menjadi bahan perbincangan KPD, sebagaimana Direktur 
Jenderal Food and Agriculture Organization (FAO) Addeke H. Boerma mengadovokasi pembentukan cadangan pangan secara domestik dan regional, asistensi makanan dari negara besar ke negara berkembang dan kecil, dan pembentukan sistem peringatan dini untuk menangani bencana kelaparan yang sangat bisa terjadi kedepan (Boerma, 1975). Ide ini lantas diimplementasikan ke wilayah Afrika, Asia dan Amerika Latin supaya menjalankan swasembada nasional. Indonesia adalah salah satu gugusan dari proses difusi strategi Revolusi Hijau yang belakangan menciptakan malapetaka baru, yakni degradasi ekologi dan beberapa persoalan pembangunan.

Pada tahun 1986, Bank Dunia merilis laporan yang berjudul Poverty and Hunger menyediakan perluasan definisi ketahanan pangan yang disebutnya sebagai keterjangkauan akses bagi seluruh manusia untuk mencukupi kebutuhan makanan demi kelangsungan dan kesehatan kehidupan mereka (World Bank, 1986). Dalam tingkat rumah tangga (household), ketahanan pangan dicapai hanya jika rumah tangga memiliki kemampuan untuk membeli dan mencukupi kebutuhan makanan. Laporan ini menaklik bahwa orientasi ketahanan pangan di tingkat terkecil yaitu rumah tangga didefinisikan sebagai kemampuan untuk membeli makanan ketimbang mengikuti program pemerintah yaitu swasembada pangan atau memproduksi pangan sebagai strategi subsisten yang menunjukkan adanya pergeseran tujuan keamanan secara semula.

Clapp dan Cohen (2009) menganggap laporan itu yang memuat konsep defenisi hingga tawaran kebijakan secara tersirat sebagai pengarusutamaan isu pembangunan melalui "program penyusaian struktural (structural programme adjusments)", liberalisasi perdagangan, dan integrasi pasar global sebagai strategi jitu untuk memenuhi kebutuhan pangan masyarakat. Wacana ketahanan pangan yang digelumbungkan oleh Bank Dunia terkesan sebagai aktifitas yang menggiring masyarakat menyadari bahwa pendapatan personal, pasar, dan cara kerja sistem pangan global yang ketat akan menjamin ketahanan pangan dibanding menyerahkan semuanya kepada negara (Clapp \& Cohen, 2009).

Tampaknya definisi di atas hanya terkesan seadanya - sekaligus tidak menyentuh pada persoalan mendasar terhadap insekuritas. Ketahanan pangan kemudian secara bertahap berkembang yang tidak hanya melihat aspek ekonomi semata tetapi mengikutsertakan implementasi kebijakan yang tepat yang berfokus kepada distribusi dan ketersediaan akses pangan kepada individu yang lebih membutuhkan. Amartya Sen lantas menyodorkan definisi ketahanan pangan yang harus dikembalikan kepada subjeknya secara khusus dan membingkainya kepada persoalan pembangunan (Sen, Famines, 1980). 
Ide ini dikenal dengan "Freedom from Want". Tawaran Sen kemudian diterima oleh PBB dengan memposisikan ketahanan pangan masuk dalam klasifikasi keamanan manusia. Selanjutnya, pada tahun 1996 berlangsung World Food Summit di Roma menggagas sebuah definisi ketahanan pangan yang direfleksikan melalui pendekatan holistik untuk menyentuh sebuah akar permasalahan sesungguhnya, yaitu: "Food security exists when all people, at all times, have physical, social and economic access tosufficient, safe and nutritious food that meets their dietary needs and food preferences for an activeand healthy life (FAO, 2006)."

Dalam tingkat rumah tangga (household), ketahanan pangan dicapai hanya jika rumah tangga memiliki kemampuan untuk membeli dan mencukupi kebutuhan makanan. Dokumen ini menaklik bahwa orientasi ketahanan pangan di tingkat terkecil yaitu rumah tangga didefinisikan sebagai kemampuan untuk membeli makanan ketimbang mengikuti program pemerintah yaitu swasembada pangan atau memproduksi pangan sebagai strategi subsisten yang menunjukkan adanya pergeseran tujuan ketahanan secara semula. Jelasnya, kerawanan pangan muncul dari akibat ketidaktersediaan akses yang dialami oleh rumah tangga.

Penulis menilai bahwa definisi yang ditawarkan oleh Bank Dunia penting untuk diperhatikan dan dikritisi, sebab ketahanan pangan identik dengan isu-isu pembangunan bebasis arus utama yang ditangani melalui program penyusaian struktural, liberalisasi perdagangan, dan integrasi ke pasar global sebagai cara memenuhi lingkup kebutuhan pangan yakni rumah tangga dan individu. Dengan kata lain, perbincangan ketahanan pangan lekat dengan logika pasar dan berpijak pada orientasi pembangunan modernis. Sebagaima penghayatan Bank Dunia bahwa persoalan dasar adalah kurangnya daya beli individu, sehingga pendapatan perseorangan yang memadai, pasar, dan cara kerja sistem pangan dunia menjamin ketahanan pangan daripada sentralitas negara dalam mengatur ketahanan pangan.

Jadi, jalannya ketahanan pangan adalah upaya menagih tanggung jawab setiap orang untuk mereduksi atau menghindari kerawanan melalui prinsip kompetisi pasar guna terciptanya akses pangan. Orang miskin harus bertanggung jawab untuk mengatasi kelaparan secara mandiri dengan menghasilkan lebih banyak pendapatan atau meningkatkan produktivitas pangan melalui skema pembangunan modernis dengan mengadopsi teknologi Revolusi Hijau. Kesuksesan strategi ini bergantung pada 
kemampuan strategi tersebut menjawab persoalan mendasar. Misalnya, tentang akses dan kepemilikan tanah, skenario pola tanam, ketentuan perdagangan dan jenis peluang mendapatkan upah, serta dinamika harga pangan secara regional dan global - di mana kesemuanya ini sangat fluktuatif.

Pendekatan ekonomi-politik Marxis menilai strategi ketahanan pangan yang ditawarkan oleh Bank Dunia dengan menyediakan perhatian pada agenda pembangunan justru menciptakan krisis pembangunan. Penekanan mereka ada pada bagaimana kontradiksi pembangunan kapitalis dan artikulasinya dengan beragam bentuk produksi komoditas menjadi biang krisis pangan dunia tahun 1970-an. Persoalan lebih mendasar lainnya adalah ketahanan pangan nasional justru dianalisis secara relasional dengan ketahanan pangan rumah tangga (Wisner, Weiner, \& O'Keefe, 1982). Akibatnya, penanganan ketahanan pangan yang dilakukan oleh negara besar justru menimbulkan kerawanan pangan bagi negara berkembang dan miskin. Michael Redclift mengklaim bahwa strategi ketahanan pangan pada akhirnya menciptakan suatu ilusi, di mana Amerika Utara dan Eropa Barat telah menghasilkan struktur regional yang menjadi penghalang utama dalam menciptakan keswasembadaan perseorangan (self-sufficiency) dalam produksi pangan di negara berkembang dan miskin (Redclift, 1987). Pembuktiannya ada pada kawasan Afrika, di mana terjadi perbudakan dan produksi tanaman tunai (cash crop) pada lahan yang ditentukan sebelumnya justru memicu kehancuran ekonomi secara sistematis.

Dalam periode yang sama, diskursus ketahanan pangan menjadi mainstream karena dikembangkan dan didifusikan oleh Bank Dunia dan FAO dengan kerangka kerja kebijakan berbasis institusional. Publikasi laporan mereka seringkali mengeksplisitkan ketahanan pangan ada pada subjek khusus, misalnya penekanan pada individu merujuk wanita miskin di Afrika atau kemampuan kelompok bisa merujuk pada petani kecil memproduksi atau membeli makanan (Smith, Pointing, \& Maxwell, 1993). Penulis menilai bahwa diskursus ketahanan pangan menjadi arus utama, sebab diposisikan sebagai strategi pembangunan modernis. Keberlangsungan implementasinya melalui skema pembangunan neoliberal yang sangat massif dijalankan semenjak dekade 1980-an. Penekanannya ada pada akses individu ke dalam sistem pangan dunia, korporatisasi melalui investasi dan modernisasi pertanian melalui peningkatan kesempatan kerja dan upah - sebagaimana poin ini secara eksplisit muncul dalam defnisi ketahanan pangan versi Bank Dunia. 
Pada tahun 1996, Deklarasi Roma tentang Ketahanan pangan Dunia mempertegas kembali definisi ketahanan pangan yang bersandar pada nilai hak asasi manasia. Ketahanan pangan terwujud apabila semua orang untuk setiap saat memiliki akses secara fisik maupun ekonomi terhadap pangan yang cukup, aman, bergizi guna memenuhi kebutuhan sesuai dengan seleranya bagi kehidupan yang aktif dan sehat (FAO, 1996). Klaim dari deklarasi ini berdasar pada akar dari kelaparan adalah kemiskinan. Orang miskin tidak mampu membeli makanan akibat distabilitas pasokan dan permintaan dunia. Faktor katalis lainnya adalah peningkatan populasi berkonsekuensi logis menciptkan penambahan kebutuhan sumber daya alam.

Dokumen dari deklarasi ini mengungkapkan bahwa perdagangan diidentifikasikan sebagai elemen kunci dalam ketahanan pangan sebab mampu memobilisasi sumber finansial dan teknologi guna meningkatkan produksi serta bantuan makanan melalui pembangunan berkelanjutan (sustainable development). Dokumen ini juga mengakui hak berdaulat negara untuk menjalankan kebijakan ketahanan pangan harus kompatibel dengan prinsip dan sistem tata kelola yang baik (good governance). Jika diamati lebih kritis maka konsepsi ketahanan pangan menurut versi konferensi ini bahwa ketahanan pangan harus diperjuangkan melalui narasi-narasi neoliberalisme dengan mengucapkan ketidakamanan pangan akibat persoalan aksesbilitas.

Pertanyaannya adalah di mana letak eksistensi hak berdaulat negara dalam memperjuangkan ketahanan pangan sementara logika neoliberalisme pangan berusaha mempersempit peran negara? Penulis menilai dari dokumen tersebut justru menunjukkan secara implisit tentang hak berdaulat pasar bukan hak berdaulat negara. Sebab ketahanan pangan hanya didefinisikan melalui upaya peningkatan pasokan dan aksesbilitas makanan melalui pembelian di pasar dunia sekaligus peningkatan produksi lokal yang dipicu oleh investasi.

Meskipun definisi ketahanan pangan kian menampung beragam sudut pandang dan fokus kebijakan, akan tetapi masih memiliki beragam kekurangan secara mendasar, khususnya memposisikan agenda ketahanan pangan sebagai ruang-ruang yang memperlebar eksploitasi bagi korporasi dan negara maju kepada petani dan negara berkembang. Atas dasar itu, terdapat perlawanan konseptual yang ditawarkan oleh wacanan alternatif yang bernama 'kedaulatan pangan'. Penulis menilai bahwa kemunculan usangan wacana alternatif semacam itu didasari oleh dua pertimbangan. 
Pertama, agenda ketahanan pangan hanya merujuk pada hitungan matematis dalam meninjau terpenuhinya ketahanan pangan dan mencari penyebab insekuritas pangan. Tidak mengherankan orientasi kebijakan ketahanan pangan sangat elitis sehingga mengeklusi masyarakat dalam roda-roda kebijakan. Salah satu perhatian di sini adalah implementasi kebijakan ketahanan pangan berimplikasi pada pertanian dan penyediaan pangan, sehingga diarahkan pada kegiatan produksi pangan secara massal dan tersedianya akses orang per orang, keluarga per keluarga, dan masyarakat secara keseluruhan atas produk pangan yang dikembangkan melalui perdagangan. Jadi perdagangan adalah instrumen terpenting dalam proses ketahanan pangan. Jika terjadi kerawanan pangan, maka jalan keluarnya adalah membuka akses penyediaan pangan tambahan guna memitigasi persoalan tersebut. Kondisi ini mengharuskan negara menjadi fasilitator untuk produksi pangan massal, pengaturan perdagangan pangan, dan asistensi pangan.

Kedua, agenda ketahanan pangan kerapkali memahami masalah ketidaktersediaan dan ketidakcukupan pangan, kelaparan, dan perdagangan pangan dari sudut pandang adanya kontrol terhadap sistem produksi dan konsumsi. Sehingga, bagi para pengkritik ini lantas menilai bahwa perhatian pada sistem pangan seharusnya mengembangkan sistem pangan lokal yang berkelanjutan dan mandiri. Hal ini didasari bahwa terdapat relasi utuh antara perdagangan pangan dari tingkat lokal hingga global dalam mekanisme perdagangan pangan.

Para penggagas konsep kedaulatan pangan menganggap wacana ketahanan pangan sebagai narasi-narasi politik dari negara besar yang berusaha menjalankan ide neoliberalisme dan menjadikan aktifitas pangan sebagai instrumennya. Misalnya, definisi pangan hanya mengerucut pada perhatian subjek yang menerima makanan, sedangkan petani kecil mengalami pendisiplinan aturan pasar bebas sehingga memungkinkan mereka mengalami eksploitasi secara mendalam. Bahkan, wacana ini juga menjadi instrumen penyebaran nilai demokrasi dan agenda pembangunan, akibatnya wacana ketahanan pangan dianggap sebagai modus kuasa dari negara-negara besar. Perlawanan wacana ketahanan pangan mulai dilancarkan oleh gerakan akar rumput dan jejaring masyarakat transnasional. Jika disederhanakan, kedaulatan pangan sebagai kontra-diskursus terhadap ketahanan pangan yang hadir dalam memfasilitasi gagasan-gagasan neoliberal (Patel, 2009).

\section{Kedaulatan Pangan Sebagai Kontra Wacana}


Wajah pangan yang terglobalisasi menginvitasi beragam kritik mendalam tentang betapa diskursus ini yang dianggapnya sama sekali tidak mampu menyelesaikan persoalan mendasar di tengah insekuritas pangan. Ketahanan pangan hanya mampu dibicarakan atau ditempuh dengan menilai kondisi insekuritas pangan dapat diselesaikan dengan cara pasokan pangan (food supply), akses pangan (food access), ketahanan gizi, dst. Kesemuanya dibungkus dalam tingkat internasional dan nasional yang sama-sama menyapakati rezim pangan, dengan panduan dan strategi ketahanan pangan yang berubahubah secara periodek. Tampaknya, persoalan ini seringkali menunjukkan sisi yang lenyap untuk ditanggapi secara utuh, misalnya bagaimana negara ingin melaksanakan swasembada sementara aturan pangan internasional melalui WTO membatasi peran negara mencampuri urusan pasar pangan. Belum lagi dunia kerapkali dihantui oleh bencana kelaparan yang terjadi di negara-negara miskin dan berkembang.

Dengan persoalan esensial semacam itu terdapat respon keras dari beberapa jaringan masyarakat sipil global menyuarakan keadilan pangan, bahwa tindakan kebijakan berbasis institusional hanya menyentuh wilayah-wilayah teknis. Tidak memperhatikan sisisisi apa saja yang harus difokuskan dalam penanganan insekuritas pangan. Salah satu dari organisasi yang aktif dalam mengkritisi diskursus ketahanan pangan adalah La Via Campesina atau sering juga disebut sebagai Serikat Petani Internasional. Organisasi ini merupakan gerakan yang mengakomodir kepentingan petani kecil (peasent), petani tanpa tanah (landless farmer), masyarakat adat, buruh pertanian, dst. La Via Campesina menganggap kelompok ini adalah subjek yang seringkali menjadi objek dari diskursus ketahanan pangan. Pada gilirannya mereka termarjinalkan akibat narasi-narasi yang bermain di balik kedok ketahanan pangan, yakni neoliberalisme pangan.

Dalam membaca histrori pergerakannya, tampak jelas bahwa organisasi ini tidak eksis dengan cara gerakan reaksioner, negativis, dan ataupun nihilis. Melainkan lebih bersifat revolusioner karena berorientasi pada pembangunan tatanan alternatif. Meminjam analisis Robert Cox (1981) mengenai struktur historis maka kita dapat menyimpulkan secara sederhana bahwa La Via Campesina merupakan aktor kontrahegemonik, sebab mereka tidak hanya memperjuangkan pada isu-isu spesifik melainkan juga dalam hal struktur tatanan dunia yang hegemonik. Struktur itu adalah diskursus neoliberalisme.

Salah satu wujud resistensi mereka adalah penolakan narasi ketahanan pangan yang dibuat oleh FAO pasca Deklarasi Ketahanan Pangan tahun 1996. Disebut sebagai aktor 
kontrahegemonik karena mereka mampu memberikan diskursus alternatif, yakni kedaulatan pangan (food soverignity). Kedaulatan pangan bagi la Via Campesina adalah hak seluruh masyarakat, bangsa dan negara untuk menyediakan dan mengembangkan kapasitas mereka dalam memproduksi kebutuhan dasar pangan yang sesuai dengan kondisi sosial, ekonomi dan budaya masing-masing (Via Campesina, 1996). Dengan kata lain, kedaulatan di sini bermaksud kemandirian untuk menentukan dan mengendalikan sistem produksi, distribusi, dan konsumsi pangan. Jadi, kedaulatan pangan merupakan pre-kondisi menuju ketahanan pangan sesungguhnya. Penulis menilai bahwa kehadiran konsep ini sejatinya mengakomodir dua hal mendasar yang hilang dari perbincangan sekuritas pangan, yakni negara dan individu.

Jika ditinjau secara historis, awal konsep kedaulatan pangan muncul di tengah pemberontakan Zapatista di Meksiko tahun 1995. Mereka menentang keberlangsungan NAFTA yang mengakibatkan prilaku dumping Amerika Serikat dalam jumlah besar melalui komoditas jagung ke Meksiko. Akibatnya, memaksa sebagian besar petani kecil tersingkir dan masuk ke jalur migrasi internasional sebagai pekerja pertanian dan pekerja industri makanan. Kemudian, gerakan La Via Campesina mulai memasuki arena utama dari permasalahan pangan global ialah perdagangan pangan yang dinilai menciptakan ruang ketidakadilan. Suara mereka menolak aturan WTO sektor pertanian dimana melarang adanya sikap proteksionis, sementara negara maju melakukan kebijakan subsidi di sektor pertanian (Clapp, 2006). Singkatnya, wacana kedaulatan pangan yang ditawarkan oleh gerakan ini sebagai langkah diskursif.

Bersamaan dengan Deklarasi Roma yang mencetuskan definisi ketahanan pangan, Campesina turut mendeklarasikan wacana kedaulatan pangan sebagai suatu definisi, yaitu: "keadilan bagi setiap negara dalam menyediakan dan mengembangkan kapasitas mereka dalam memproduksi kebutuhan pangan secara medasar serta menghargai disparitas produksi dan budaya lokal yang ada" (Campesina, 1996). Konsep kedaulatan pangan tidak lebih dari kedaulatan nasional di bidang pertanian. Pengembangan kapasitas dalam memproduksi makananan sebagai hak utama oleh negara sekaligus menentang proses liberalisasi perdagangan dan kebijakan ekonomi dari proses penyusaian struktural pertanian. Konsep ini secara tegas memandang sistem pangan global melalui nafas neoliberal tidak sekedar menjadi mode pengaturan perdagangan pangan, tetapi juga diiringi dengan penyebaran model dan nilai pembangunan liberal (Bello, 1999). 
Deklarasi Campesina menekankan tujuh prinsip dalam konsep kedaulatan pangan, yaitu: (1) makanan adalah hak dasar manusia; (2) reformasi agraria harus memberikan kepemilikan (ownership) dan kontrol kepada masyarakat adat lokal (indigenous people); (3) kedaulatan pangan adalah upaya penggunaan dan pengendalian sektor pertanian dengan prinsip keberlanjutan terkait tanah, air dan benih dalam melestarikan keanekaragaman hayati; (4) basis utama kedaulatan pangan ialah hak bagi petani untuk secara bebas menggunakan dan melindungi sumber pangan sekaligus sebagai mata pencarian mereka; (5) kebijakan pangan nasional harus memprioritaskan produksi untuk kebutuhan konsumsi domestik dan kedaulatan pangan; (6) sistem institusi multilateral dan spekulasi finansial global tidak memberi jaminan atas kemandirian pangan, maka perlu dibentuk kode etik internasional (code of conduct) untuk korporasi transnasional dan penciptaan sistem peraturan dan perpajakan secara terlembaga; (7) pangan tidak dapat dijadikan sebagai senjata politik ataupun rezim negara maju.

Konsep ini kemudian menitikberatkan perhatiannya kepada petani kecil (peasent) yang sepatutnya menjadi aktor utama dalam merumuskan kebijakan pangan dalam berbagai tingkat. Posisi petani acapkali tidak memiliki otonomi pengambilan keputusan bahkan dijadikan sebagai objek dari kebijakan pangan. Dengung ini bermakna kepada upaya legitimasi hak asasi petani yang sebagai bagian yang sah dari hak asasi manusia. Campesina memandang peasent termasuk ke dalam kelompok tertindas yang memerlukan mekanisme perlindungan khusus.

Pada tahun 2001, Campesina mendeklarasikan institusionalisasi hak-hak asasi petani ke dalam hak asasi manusia internasional. Deklarasi ini berjudul "Our World is Not for Sale" yang artinya sebagai hak masyarakat untuk menentukan kebijakan pertanian dan pangan mereka; melindungi dan mengatur produksi dengan skema perdagangan pertanian domestik untuk mencapai tujuan pembangunan yang berkelanjutan; upaya kemandirian pangan; dan membatasi prilaku dumping di pasar mereka sendiri. Patut digarisbawahi, konsep ini tidak menolak sistem perdagangan global melainkan mendorong perumusan kebijakan dan praktik perdagangan yang melanggengkan tersedianya hak individu yang aman, sehat, dan berkelanjutan dengan visi ekologis (Campesina, 2001). Selain itu, deklarasi ini mendesak pelarangan produksi dan perdagangan benih, makanan dan produk dengan rekayasa genetik (Genetically Modified Organisms). Deklarasi kedaulatan pangan akhirnya dikenal sebagai kontra diskursus - yangmemposisikan jantung persoalan 
kelaparan dan kemiskinan sebagai hasil dari globalisasi pangan dan pertanian yang dikumandangkan oleh institusi multilateral seperti Bank Dunia dan WTO, korporasi agribisnisnis transnasional, dan negara-negara terkemuka yaitu AS dan Uni Eropa.

Pertanyaannya kemudian, apakah konsep ketahanan pangan dengan kedaulatan pangan yang terlihat oposisional dapat relasional? Sebuah laporan International Assement of Agricultural Knowledge, Science and Technology for Development (IAASTD) memuat kedua konsep diatas dapat dipadukan, sebab wacana-wacana yang ditawarkan bersifat kompatibel dalam mereduksi masalah sesungguhnya dari insekuritas pangan. Penelitian ini mempertemukan otoritas pemikir dengan berbagai latar belakang keilmuan, aktivis pangan, institusi internasional dan 57 negara. IAASTD mengakui program pertanian berkelanjutan dan wacana kedaulatan pangan dianggap penting. Selain itu, IAASTD mengklaimpengetahuan pertanian, teknologi dan sains memiliki peran penting menuju kedaulatan pangan dan keamanana pangan (IAASTD, 2009). Kesimpulannya ialah konsep ketahanan pangan dan kedaulatan pangan bukanlah konsep oposisional melainkan sebagai konsep yang saling terkait yang mencakup akses, distribusi, keamanan, dan kesetaraan.

Meskipun dianggap konvergen, laporan ini secara tersirat memposisikan praktik rekayasa genetika pangan tidak dapat menyelesaikan masalah utama dari persoalan pangan yaitu kelaparan. Narasi tentang kesepakatan yang dimuat oleh IAASTD memperlihatkan situasi resisten bagi Kanada, Australia dan AS yang menilai praktik bioteknologi bukanlah masalah utama. Jika diperhatikan, sikap yang dituai oleh ketiga negara tersebut sebagai prilaku politik yang berusaha mengamankan korporasi agrbisnisnya. Mereka berpandangan kehadiran rekayasa genetik sangat penting bagi revolusi genetika dalam sektor pertanian guna menghindari krisis dan inflasi harga pangan. Pandangan tersebut dianggap spekulatif bagi aktifis yang terlibat dalam IAASTD. Mereka memandang tidak ada kausalitas antara peningkatan produktifitas dengan pemenuhan hak untuk makanan sebab semuanya berlangsung dibawah kendali korporasi agribisnis transnasional.

Hal ini juga terjadi juga pada disparitas pandangan antara ilmuwan sosial dan ilmuwan eksakta dalam melihat rekayasa genetik pada pertemuan IAASTD (Jarosz, 2014). Di satu sisi, ilmuwan eksakta melihat kehadiran teknologi/rekayasa pangan justru mampu meminimalisir kelaparan yang kemudian dapat meningkatkan produksi pangan. Di sisi lain, ilmuwan sosial menilai kehadiran tersebut justru memperluas insekuritas pangan dan risiko sosial dan lingkungan, selain itu mereka menunjukkan bahwa kelaparan terjadi bukan semata-mata kurangnya ketersediaan pangan, melainkan lonjakan kelaparan akibat 
tidak seimbangnya distribusi output pangan dan kurangnya hak politik, sosial dan ekonomi (Keen, 2008). Terlepas upaya konter-konseptual sekaligus wacana yang diusung oleh Via Campesina mengenai kedaulatan pangan, tidak sedikit juga ahli mengkritik kembali pendekatan ini, seperti Henry Bernstein, dan Hannah Wittman, Annette Desmarais dan Nettie Wiebe.

Dalam tulisan Bernstein (2014) sebenarnya membenarkan sekaligus mengagumi satu elemen kunci kedaulatan pangan adalah kritik secara tuntas pada korporasi industri pertanian. Sebab, ketidakadilan berulangkali diisi oleh korporasi-korporasi yang menjadi oktopus dari neoliberalisme itu sendiri. Bernstein lantas skeptis terhadap dua elemen lain, yakni orientasi advokasi jalan petani sebagai basis bagi keadilan pangan berkelanjutan. Kedaulatan pangan meletakkan petani kecil, dengan klaim bahwa petani pemilik lahan sempit (small producers) menjalankan pertanian agroekologi yang dipahami sebagai pertanian yang menggunakan input dan tenaga kerja yang rendah mampu memberikan makan dunia (Bernstein, 2014). Elemen berikutnya adalah program yang mengkoneksikan aktivitas pertanian skala kecil dengan kebutuhan pangan bagi kelompok non-petani, di mana secara populasi terus meningkat. Di tengah kritik itu, penulis menilai Bernstein seolah menafikan salah satu tawaran orisinil dari konsep kedaulatan pangan, yakni atensi terhadap perempuan petani. Konsep ketahanan pangan tentu absen membicarakan kehadiran mereka, sebab pandangannya menyebut petani masih dilihat secara umum. Tidak dengan konsep kedaulatan pangan. Pertanyaan ini bisa diuji dengan bagaimana posisi, peran dan kontribusi mereka dalam penyediaan pangan keluarga petani yang subsisten dan perjuangannya untuk keluar dari arena ekonomi politik neoliberalisme yang melanggengkan wujud patriarkis. Terlepas begitu, tulisan dari Bernstein layak menjadi bahan dasar untuk memahami konsep kedaulatan pangan secara epistemologis dan aksiologis dari perspektif ekonomi-poliyik produksi pangan di tengah diskursif kapitalisme global.

Demikian juga dalam tulisan Hannah Wittman, Annette Desmarais dan Nettie Wiebe berjudul The Origins \& Potential of Food Sovereignty (2010) turut mencela konsep kedaulatan pangan yang belum dapat dikategorikan sebagai paradigma pengetahuan ilmiah yang tepat. Jelasnya, konsep kedaulatan pangan merupakan suatu pengetahun yang sedang mentas (emergent science) yang bersumber dari praktek dan produksi pengetahuan kelompok-kelompok masyarakat akar rumput yang dipelopori dan diadvokasi melalui 
proses politik gerakan sosial. Sementara konsep ketahanan pangan sudah lebih mapan. Telepas dianggap bukan sebagai paradigma paripurna dalam sistem pangan, poin terpenting untuk kita catat adalah kehadiran mereka ingin menunjukkan bahwa konsep kedaulatan pangan adalah pendekatan alternatif yang patut untuk diperjuangkan. Sebab, konsep ketahanan pangan dianggap bermasalah karena perbedaan itu jelas bahwa kedaulatan pangan berbasis pada kehendak masyarakat sipil sementara ketahanan pangan berbasis kebijakan institusional yang digerakkan oleh modus kuasa dan ide. Menjadi konsep yang mapan juga ditopang oleh kehadiran kapabilitas material berupa tindakantindakan operasional dan teknis, serta dikembangkan oleh berbagai lembaga riset dan lembaga-lembaga internasional dan multilateral. Seolah-olah ketahanan pangan hanya merujuk pada hitungan matematis dalam meninjau terpenuhinya ketahanan pangan dan mencari penyebab insekuritas pangan. Tidak mengherankan orientasi kebijakan ketahanan pangan sangat elitis sehingga mengeklusi masyarakat dalam roda-roda kebijakan. Salah perhatian di sini adalah implementasi kebijakan ketahanan pangan berimplikasi pada pertanian dan penyediaan pangan, sehingga diarahkan pada kegiatan produksi pangan secara massal dan tersedianya akses orang per orang, keluarga per keluarga, dan masyarakat secara keseluruhan atas produk pangan yang dikembangkan melalui perdagangan. Jadi perdagangan adalah instrumen terpenting dalam proses ketahanan pangan. Jika terjadi kerawanan pangan, maka jalan keluarnya adalah membuka akses penyediaan pangan tambahan guna memitigasi persoalan tersebut. Kondisi ini mengharuskan negara menjadi fasilitator untuk produksi pangan massal, pengaturan perdagangan pangan, dan asistensi pangan.

Diskursus ketahanan pangan berkumandang secara masif mengundang para pengkritik menunjukkan pandangan mereka dengan dalil bahwa diskursus ini sama sekali tidak mapan secara pengetahuan maupun praktis. Dianggap bermasalah sebab hanya melihat masalah ketidaktersediaan dan ketidakcukupan pangan, kelaparan, dan perdagangan pangan dari sudut pandang adanya kontrol terhadap sistem produksi dan konsumsi. Pengkritik ini lantas menilai bahwa perhatian pada sistem pangan seharusnya mengembangkan sistem pangan lokal yang berkelanjutan dan mandiri. Hal ini didasari bahwa terdapat relasi utuh antara perdagangan pangan dari tingkat lokal hingga global dalam mekanisme perdaganagn pangan. Jadi, persoalan dan tantangan sistem pangan sepatutnya diatasi dengan menyandarkan pada persoalan hak ketimbang persoalan distribusi dan perdagangan. Jadi kata kunci mengenai kedaulatan pangan adalah tegaknya 
jaminan hak atas pangan. Dengan demikian, fakta dari insekuritas pangan berupa kelaparan ialah ketidadaan hak atas pangan. Atas dasar itu, tulisan ini yang memfokuskan pada isu kelaparan patut juga ditinjau secara utuh berdasarkan kajian keamanan internasional yang merupakan lingkup perhatian dalam studi hubungan internasional. Pertimbangan pengetahuan semacam ini patut diakomodir dengan beberapa alasan mendasar. Pertama, fakta lingkungan internasional dan domestik semakin kabur semenjak isu non-tradisional dalam hubungan internasional mengingat resonansi transnasionalisme kian mengemuka. Kedua, beberapa konsep-konsep ketahanan pangan di atas juga telah diduplikasi dalam perhatian pemikir hubungan internasional, sebab tebentuk pola neksus antara aktor-aktor global dalam memposisikan sumber daya pangan sebagai komoditas dan kapasitas suatu aktor. Ketiga, di tengah menguatnya isu-isu ancaman non-militer menjadi isu pangan mendapatkan tempat penting sebagai upaya pendalaman dan perluasan kajian keamanan.

\section{Studi Keamanan dan Insekuritas Pangan}

Insekuritas pangan sebenarnya dapat dilalui dari tiga sudut pandang studi keamanan, yaitu pendekatan Neorealisme, pendekatan Keamanan Manusia, dan pendekatan Keamanan Kritis (emansipatoris). Ketiga pendekatan ini menunjukkan variasi dalam menjawab pertanyaan esensial, apa yang dimaksud dengan ketahanan pangan dan siapa yang menjadi objek referen atas sekuritisasi tersebut. Kajian ketahanan pangan yang sifatnya begitu luas, maka pembahasan ini mengkhususkan dalam menelaah bagaimana bentuk insekuritas pangan berupa kelaparan dilihat oleh tiga pendekatan tersebut. Hal ini didasari oleh fakta bahwa hampir 5,3 juta anak di seluruh dunia telah meninggal akibat malnutrsi setiap tahunnya (UNICEF, 2006).

Penulis menilai bahwa diskusi seputar ketahanan pangan terlebih dahulu didudukkan pada isu utama yang muncul setiap tahun dan dekade. Isu itu adalah kelaparan. Harus digarisbawahi bahwa kelaparan bukanlah sebuah fenomena alami dan bukan juga sebagai produk dari ketidakseimbangan antara kebutuhan pangan dengan laju populasi tinggi yang sering dikumandangkan oleh perspektif Malthussian ${ }^{1}$.

\footnotetext{
1 Perspektif Malthus melihat krisis pangan yang berlangsung karena adanya ketidakseimbangan antara ketersediaan (supply) dengan kebutuhan (demand) saat angka kebutuhan lebih tinggi dari ketersediaan yang berkonsekuensi pada krisis. Malthus menilai bahwa peningkatan populasi yang besar akan memiliki
}

RIR | Volume 2, Nomor 2, 2020163 
Kelaparan adalah bencana kemanusiaan yang eksis di tengah kita, namun perhatian struktural dan sistemik justru semakin menjauh pada persoalan ini. kehadiran pendikatomian semacam ini ialah keterbatasan kita dalam memahami definisi keamanan itu sendiri. Hal ini tergambar dalam fakta sosial bahwa di satu sisi terdapat peningkatan populasi yang mengadapi kelaparan, di sisi lain meningkatnya fokus strategi dan kontrol negara terhadap produksi dan ketersediaan pangan. Persoalannya, terdapat fokus besar negara dalam memenuhi kebutuhan pangannya, namun tidak diiringi dengan perhatian utama dalam menyelesaikan persoalan kelaparan. Corak ini menunjukkan asumsi kritis, bahwa kelaparan boleh jadi sebagai produk dari kebijakan ketahanan pangan itu sendiri. Sebelum jauh meninjau bagaimana dan mengapa pendekatan keamanan kritis patut menjadi pertimbangan menganalisis lebih lanjut mengenai ketahanan pangan dewasa ini, penulis terlebih dahulu pertama-tama akan menunjukkan limitasi-limitasi dari pendekatan arus utama keamanan internasional, yakni Neorealisme dan Keamanan Manusia [menurut mazhab Kopenhagen].

Neorealisme menaruh perhatian yang lebih mendalam terhadap aktor negara. Pendekatan ini menyadari bahwa aktor tersebut yang tidak hanya terlegitimasi dalam politik keamanan, tetapi juga sebagai objek yang harus diamanankan. Dalam nilai keamanan, negara harus memaksimalkan kekuatannya dalam arena internasional yang bersifat anarkis. Bagi realisme klasik, definisi ini hanya mencakup bidang militer semata. Akibatnya, tindakan negara dalam urusan ketahanan pangan bukan menjadi perhatian utamanya. Meskipun demikian, upaya perluasan definisi mengenai kekuatan ekstra-militer turut dipertimbangkan melalui kepentingan negara yang dapat ditelusuri melalui pemikiran neo-realis.

Ide neorealis memperbolehkan kita untuk menganalisa isu keamanan melalui lanskap peran negara sebagai objek referen. Ketahanan pangan merupakan ihwal terpenting bagi negara sebagai kekuatan ekonomi sekaligus kekuatan politik. Hal ini didasari oleh kehadiran populasi yang sehat merupakan populasi produktif yang akan menjadi sumber kekuatan suatu negara. Shutao Gao (2008) menekankan ketahanan pangan sebagai, "basic guarantee for national security" (p. 42). Persoalan pangan berupa 
kelaparan turut diperhatikan dari perspektif ini. Kelaparan merupakan konsekuensi logis dari perang dan konflik - bahkan hadirnya konflik yang besar berlangsung pada upaya mempertahankan atau menganeksasi teritorial yang memiliki sumber pangan yang besar (J.R.Tarrant, 1981). Pandangan ini sebenarnya diilhami oleh Kanneth Waltz (1979) dengan diktum populernya, yaitu: "in anarchy [the international system], security is the highest end, and that only if survival is assured can states safely seek other goals such as tranquillity, profit and power (p. 126)". Secara tersirat, Waltz memposisikan keamanan lebih dari sekedar proses survival tetapi juga mencakup perilaku kompetitif dalam sistem internasional. Dalil ini mengafirmasi bahwa kebutuhan survival suatu negara tidak hanya menggunakan instrumen militer.

Konteks ketahanan pangan dalam pandangan neorealis dapat dihubungkan melalui tersedianya institusi global yang mengatur pola kerja sama dalam permintaan dan penawaran terhadap ketersediaan pangan (kelembagaan neoliberal). Asumsi dasar neorealis mengenai ketahanan pangan berarti bahwa selama pasokan pangan tersedia dengan mudah dan harga yang menguntungkan melalui pasar bebas internasional, negaranegara akan bersedia untuk berpatisipasi. Namun, saat sumber pangan menjadi langka atau tidak dapat diakses akibat lonjakan harga yang sangat cepat, maka suatu negara mendapat celah untuk menarik diri dalam kerjasama tersebut.

Perspektif ini cukup probelamatis sekaligus menaifkan persoalan mendasar dari insekuritas pangan. Beberapa kritik besar menunjukkan bahwa hasutan perspektif ini menunjukkan agenda pangan berusaha untuk mengamankan kepentingan suatu negara yang akan menentukan agenda lain (Jones, 1999). Akibatnya, perhatian atas persoalan kelaparan bukan menjadi isu besar, sekalipun isu ini dipertimbangkan relevan namun penyelesaiannya bersifat elitis. Sekuritisasi pangan bagi pendekatan ini justru terkonsenterasi pada ketersedian pangan semata, sehingga pendekatan ini cenderung terbatas dalam mengeksplorasi hakikat keamanan itu sendiri.

Semenjak pendekatan Neorealis mendapat kontestasi yang cukup sengit akibat kegagapan dalam membicarakan esensi keamanan, maka pendekatan Keamanan Manusia yang disodorkan oleh Barry Buzan (1991) memposisikan objek referennya kepada individu atau kelompok yang acapkali menghadapi insekuritas pangan. Pendekatan ini menempatkan isu insekuritas pangan sebagai salah fokus utama keamanan itu sendiri. 
Jelasnya, pendekatan ini mengalihkan beberapa ahli dan praktisi keamanan dalam menghadapi tantangan kelaparan sebagai widespread insecurity.

Pada dasarnya, mazhab Kopenhagen menilai bahwa terdapat lima arena keamanan yang harus dilindungi oleh negara, yakni politik, militer, ekonomi, masyarakat, dan lingkungan. Pengamatan keamanan memungkinkan negara mensekuritisasi isu insekuritas yang muncul. Isu itu terlebih dahulu terposisikan sebagai ancaman eksistensial melalui peryataan (speech act) yang diterima oleh publik yang menjadi target sekuritisasi (target audience). Dengan menyatakan keamanan sebagai suatu pernyataan, maka menjadikan keamanan merupakan sebuah proses konstruksi sosial dan juga memberikan kesempatan bagi agen sebagai pelaku keamanan (securitizing actor) guna menyatakan bahwa berbagai isu berpotensi menghadorkan ancaman eksistensial (existential threat) bagi manusianegara. Apabila publik menjadi target sepakat dari penyataan yang dilakukan oleh pelaku keamanan, maka dapat tersimpulkan bahwa proses sekuritisasi berlangsung sukses. Proses sekuritisasi yang disampaikan oleh Buzan sebenarnya memuat tiga klaim. Pertama, adanya pandangan bahwa suatu objek tertentu sedang menghadapi ancaman eksistensial. Objek ini bisa petani, masyarakat, kelompok sosial, dan negara. Kedua, adanya permintaan guna melakukan tindakan di luar kenormalan - politisasi- sebagai justifikasi melakukan tindakan kedaruratan. Ketiga, adanya upaya guna meyakinkan publik bahwa tindakan di luar prosedur normal tersebut dapat dibenarkan selama mampu mengatasi ancaman eksistensial. Kerangka anlisis sekuritisasi ini lantas banyak digunakan bagi beberapa analisis dalam menjelaskan fenomena ancaman non-tradisional, khususnya mengenai kelaparan.

Meskipun pendekatan ini hirau pada isu tersebut, pendekatan ini cenderung menguraikan persoalan kelaparan untuk dikelompokkan melalui variabel seperti hak, kebebasan dan insekuritas. Akibatnya, pengidentifikasian kelaparan seringkali sulit dibedakan - apakah mengacu pada kekurangan, insekuritas manusia, ataukah pada kerusakannya. Seperti pemaparan awal di atas, pendekatan ini mulanya dihasut dari pemikiran Amartya Sen mengenai kebebasan dari ancaman dan keinginan. Pendekatan ini kemudian berpandangan bahwa kekurangan adalah bentuk insekuritas itu sendiri. Pertanyaanya kemudian, pada titik manakah persoalan pangan menjadi perhatian keamanan.

Konsepsi keamanan manusia teridentifikasi dari United Nations Development Program melalui Laporan Pembangunan Manusia tahun 1994 yang mencakup, "safety 
from such chronic threats as hunger, disease and repression. And ... protection from sudden and hurtful disruptions in the pattern of daily life (1994, p. 23)". Jika disederhanakan, insekuritas ialah ketidakmampuan atau kegagalan dalam memprioritaskan insekuritas disaat keamanan manusia dipahami secara luas. Uniknya, ancaman yang tersedia direspon melalui konsep yang tuntas, sedangkan ancaman fisik yang sifatnya langsung yaitu kelaparan justru tidak mendapat perhatian yang lebih jauh. Pengucilan ini menyoroti bahwa isu kelaparan perlu bersaing untuk mendapat posisi sebagai agenda prioritas utama suatu negara. Lebih jauh lagi, pengecualian ini sebagai hasil dari konsep kompetitif - di mana ancaman keamanan harus diperjuangkan untuk mendapat keuntungan. Hal ini didasari oleh limitasi ontologi yang memungkinkan masalah ini tidak ditangani dengan baik dan justru didominasi melalui pendekatan negara sentris. Akibatnya, logika ketahanan pangan hanya mengikuti kaidah ketersediaan makanan yang kompeten dan kompetitif, sehingga menyingkirkan masalah utama dari kelaparan (Kunjoro, Jamil, \& Mathur, 2013).

Hal ini menunjukkan bahwa pendekatan keamanan manusia masih belum memberikan tawaran yang memadai atau setidaknya menunjukkan mengapa isu kelaparan kompatibel dengan isu keamanan manusia lainnya. Grayson (2008) berpendapat bahwa keterbatasan perspektif keamanan manusia karena adanya prinsip-prinsip sekuritas manusia ke dalam ortodoksi keamanan - yaitu memfasilitasi penyatuan keamanan manusia sebagai variabel penting dari kalkulasi pemerintah (Grayson, 2008). Duffield dan Waddel (2006) mengatakan pendekatan ini tidak lebih dari perangkat neo-kolonialisme - yang melegitimasi negara Barat dalam mengintervensi negara-negara berkembang (Duffield \& Waddell, 2006). Dalam istilah yang sama, Rajaonarison (2014) menilai ide keamanan manusia telah menjadi 'modus operandi' dalam menyelesaikan persoalan pangan yang dilakukan negara besar dan korporasinya yang menawarkan misi kemanusian jutru diboncengi dengan agenda neoliberal (Rajaonarison, 2014). Jika diintisarikan mengenai kritik tersebut, maka perspektif keamanan manusia yang tadinya berfokus pada manusia sebagai objek referen, namun penyelesaiannya masih dikooptasi oleh negara (pemerintah) - yang pada akhirnya mengarah pada eksepsi kelaparan sebagai bentuk security matter.

\section{Gugatan Keamanan Kritis}

Dari dua pendekatan di atas tampak mengandung limitasi secara konseptual. Gugatan dari keduanya telah murni ditawarkan oleh pendekatan Keamanan Kritis atau Mazhab Welsh. 
Pemikiran ini sebenarnya sebagai pengembangan tradisi pemikiran sosial Mazhab Frankfurt atau yang biasa disebut sebagai Neo-Marxianisme. Pemikiran ini lantas mengilhami para pemikir keamanan internasional. Nama paling menonjol itu adalah Ken Booth. Berdasarkan dari pendekatan Keamanan Kritis, penulis menilai sebagai pendekatan yang mampu masuk ke persoalan yang jauh lebih intim dan dalam ketimbang pendekatan Realis dan Keamanan Manusia, khususnya menyoal kerawanan pangan dan kelaparan. Pada dasarnya, pendekatan ini berusaha mendobrak dogmatisme dari arus pemikiran mainstream dalam melihat dan memposisikan makna keamanan itu sendiri.

Pada mulanya, pendekatan ini berdiri sebagai metode pemikiran kritis guna merespon kegagapan teori yang sudah berkembang secara arus-utama. Terlebih khusus, misalnya, praktk dan kebijakan negara tidak akan pernah berlangsung dalam arena hampa. Melainkan eksis dan bertindak di dalam, di sekitar, dan di atas kehidupan individu. Dengan demikian, pendekatan kritis ini melengkapi kebaruan tradisi keamanan internasional, bahwa di alam raya modernitas seperti kemunculan isu kelaparan bukanlah fenomena alam atau bersifat given seperti yang keyakinan paradigm Malthussian. Thomas Malthus yang menawarkan teori kependudukan membangun preposisi bahwa pertumbuhan pangan mengikuti deret aritmetrik, bukan deret eksponensial. Maksudnya, manusia tidak dapat terhindar dari masalah kelaparan akibat kebutuhan pangan kian waktu terus meningkat. Sebaliknya, pemikir keamanan kritis seperti Benjamin Shepherd (2012) meyakini bahwa klaim Malthussian mengenai kelaparan itu sudah menjadi hukum absolut seiring dengan populasi penduduk yang kian bertambah adalah pandangan yang mensimplifikasi keadaan dan keliru. Menurut dia, persoalan kelaparan bukanlah sesuatu keadaan terberi oleh kondisi alamiah, melainkan suatu masalah struktural.

Penulis memandang bahwa pendekatan keamananan kritis telah menghasilkan tiga signifikansi utama dalam kajian keamanan internasional, yaitu (1) pendalaman cakupan keamanan; (2) perluasan cakupan keamanan; dan (3) pemanjangan cakupan keamanan. Pernyataan pertama merupakan kritik terhadap pendekatan studi keamanan tradisional, sekaligus rekonstruksi pendekatan baru. Bagi Wyn Jones (1999), pernyataan kedua sebagai upaya keluar dari perdebatan isu-isu non militer dan pernyataan ketiga meliputi objek referen bagi keamanan kritis (Jones, 1999). Perluasan cakupan keamanan merupakan fungsi dari pendalaman cakupan keamanan itu sendiri. Perbincangan keamanan (ideasional dan praktis) akan mencerminkan konsepsi secara natural mengenai realitas politik dunia. Artinya, isu keamanan hanya dapat diperluas berdasarkan asumsi-asumsi pokok teori 
politik. Sementara itu, pemanjangan cakupan keamanan sebagai bentuk restrukturisasi keamanan itu sendiri, akibatnya objek referen bagi pendekatan ini menolak siapa dan apa sebagai struktur kategorial yang memprevilasi teori politik (Booth, 1999). Bahkan, negara bukanlah satu-satunya objek referen untuk keamanan itu sendiri. Hal ini berdasarkan dari tiga alasan, yaitu: (1) negara eksis atau tidak eksis dalam urusan keamanan (internal dan ekternal); (2) negara merupakan penghasil keamanan (internal dan eksternal) yang dikategorikan sebagai sarana dan bukan sebagai tujuan keamanan; dan (3) negara terlalu beragam dalam karakternya untuk dijadikan sebagai dasar bagi teori keamanan yang komprehensif (1999, p. 320).

Ken Booth dalam karya seminalnya Theory of World Security (2007) menuangkan kelanjutan dari tradisi pemikiran Mazhab Frankfurt dengan upaya membangun kesadaran kritis/reflektif dalam membongkar ortodoksi paradigma mainstreammengenai teori keamanan. Hal ini didasari oleh skeptisme bahwa teori-teori pada dasarnya dibentuk oleh suatu konteks di mana mereka berada. Booth kemudian mengajak kita untuk menyadari bahwa tujuan teorisasi pada hakikatnya memiliki tugas emansipasi (praksis) atau meminjam istilahnya, yaitu "theorizing that seeks to struggle against the injustices of the world (p. 43). Emansipasi adalah konsep kunci bagi pendekatan ini. Dalam arti yang sederhana, emansipasi adalah agenda membebaskan manusia dari berbagai belenggu dan ancaman yang meliputi tekanan fisik dan ikatan terhadap segala bentuk paksaan/penindasan. Kelaparan adalah salah satu dari ikatan insekuritas tersebut, yang menghasilkan wujud kekerasan fisik (malnutrisi dan kematian).

Kelaparan menjadi penting untuk diulas melalui pendekatan ini, dengan dasar bahwa adanya kekerasan akan menghambat emansipasi itu sendiri. Hubungan kekerasan dan kelaparan bersifat interdependen. Jelasnya, kekerasan tidak sekedar dilihat dari bentuk kerusakan fisik yang ditimbulkan oleh satu manusia dengan manusia lainnya, tetapi kekerasan yang jauh lebih besar yang cenderung dihasilkan dan dinaifkan oleh negara yaitu kekerasan struktural. Keamanan kritis dalam melihat kelaparan memainkan peran normatif mengenai apa yang harus dilakukan dalam menyelesaikan persoalan kelaparan. Bagi Shepherd, persoalan ini sepatutnya mengalami pembingkaian ulang terhadap makna keamanan secara utuh dengan prosedur yaitu mengamankan populasi yang rentan dari kekerasan struktural akibat kelaparan (Shepherd, 2012). Pembingkaian tersebut sebagai 
bentuk problematisasi ulang terhadap pembingkaian ketahanan pangan yang selama ini cenderung dilihat sebagai respon ekonomi dan politik.

Pembingkaian ulang ini juga berupaya untuk menempatkan tanggung jawab pada agensi institusional dan sistemik. Hal inilah menjadi dasar untuk menciptakan kondisi emansipasi manusia. Dalam wilayah institusional dan sistemik, pendektatan ini memposisikan penyelesaian kelaparan sama artinya dengan penyelesaian persoalan struktural, dengan membentuk kebijakan yang konsen pada masalah tersebut sebagai keputusan strategis dan taktis bagi setiap aktor atau agen yang terlibat pada insekuritas pangan. Prosedur tersebut dapat diterjemahkan melalui merancang, menerapkan, mengevaluasi dan mengukur keberhasilan dari strategi, kebijakan dan aksi untuk ketahanan pangan.

Akhirnya, dapat ditemukan bahwa persoalan kelaparan sebenarnya sebagai masalah struktural sehingga awal perbaikannya ada pada aransemen institutional. Shaw membenarkan kondisi ini bahwa paradigma keamanan yang telah eksis justru terbelenggu oleh masalah inkonsistensi inistitusional. Berdirinya keragaman institusi-institusi ketahanan pangan (level domestik, regional dan global) sebagai bentuk perhatian pada isu pangan, namun tidak berbanding lurus dengan implementasi penyelesaian insekuritas kelaparan (Shaw, 2007). Uvin (1994) kemudian secara sarkastik menyebut institusi internasional yang berfokus pada paradigma ketahanan pangan yang mengatur perdagangan justru digambarkan sebagai "International Organization of Hunger" - yang secara sistematis menciptakan kondisi yang menguntungkan bagi masyarakat kaya, sementara masyarakat miskin harus menerima kelangkaan pangan (Uvin, 1994).

Kritik ini menunjukkan bahwa institusi-institusi ketahanan pangan global justru hadir sebagai bagian dari masalah kelaparan. Jelasnya kelaparan tidak hadir sebagai kapasitas produksi, melainkan sebagai konstruksi manusia terhadap struktur politik dan ekonomi yang mengontrol bagaimana pangan dialokasikan dan dihasilkan menuju perluasan kelaparan. Sementara dalam level global, institusi FAO yang memiliki legitimasi penawaran definisi mengenai ketahanan pangan telah menjadi panduan untuk diikuti bagi setiap pemerintah, organisasi multilateral, dan korporasi agribisnis transnasional. Ironisnya, definisi-definisi ketahanan pangan terkait kelaparan tereksklusi. Pendekatan ekonomi, pembangunan dan politik justru menjadi perhatian utama atas institusi tersebut.

Stepherd menyebut kondisi ini telah menghasilkan persoalan fundamental. Pertama, definisi yang dilakukan oleh FAO telah menjadi kesepakatan absolut. Alih-alih 
untuk menentaskan produk dari insekuritas pangan yaitu kelaparan, justru definisi yang tersedia tidak mampu menyediakan kerangka kerja untuk mengevaluasi serta menguji keberhasilan dari kebijakan yang berlangsung khususnya mengatasi masalah kelaparan sebagai persoalan struktural yang kompleks. Kedua, pembingkaian insekuritas pangan terkesan pasif dan aktor yang mensekuritisasi risiko dan ancaman kelaparan mengalami absensi. Stepherd mengkritiknya dengan tegas, "There are no actors with agency that might be responsible for providing food security, nor calls to action to do so. Nor are there actors (other than the elusive 'all people') who might be experiencing, or at risk of, hunger and should be the beneficiaries of food-security analysis, strategies, policies or actions (p. 197)."

Dari serangkaian perdebatan di atas, persoalan kelaparan sepatutnya mendapat perhatian utama dalam diskusi keamanan saat ini. Wacana ketahanan pangan telah menjadi arus utama, sementara terdapat beberapa kekeliruan mendasar dalam hal ontologis maupun praksis. Persoalan ini sepatutnya menjadi nafas baru bagi sarjana-sarjana keamanan dengan memfokuskan kesadaran atas tanggung jawab moral dan ilmiah dalam memprobelematisasi ulang wacana ketahanan pangan dan persoalan kelaparan.

Upaya ini sebagai wujud emansipatoris dengan mempertimbangkan lima faktor dasar, yaitu: (1) kelaparan merupakan ancaman eksistensial bagi kehidupan manusia dan sebagai sumber yang jauh lebih besar dari bahaya fisik seperti deprivasi kepemilikan tanah, pendapatan dan modal, hak politik atau martabat dasar. Ada banyak persoalan yang ditimbulkan dari kelaparan, yang paling umum misalnya risiko dini mengalami kematian, sumber penyakit dan secara gradual menganggu perkembangan kognitif bagi anak-anak. Yang lebih memprihatinkan lagi, kelaparan dan kekurangan gizi berkonsekuensi mengikikis mata pencaharian mereka dan membatasi kapasitas mereka sebagai manusia yang merdeka, (2) berlangsungnya persoalan kelaparan yang terus-menerus terjadi, elit politik telah gagal dalam mengemban peran yang ditugaskan sebagai pelindung dan penjamin keamanan. Secara teoritis, kondisi ini dilihat sebagai kerusakan signifikan atas legitimasi politik dan legitimasi praktik keamanan, (3) secara praktis, kelaparan tentu menimbulkan konflik sosial-politik yang dapat menggangu dimensi keamanan lainnya, dan (4) kelaparan yang semakin meluas tidak hanya dirasakan bagi individu yang mengalami, tetapi difusi ancaman akan bergeser kepada komunitas masyarakat hingga negara itu sendiri. 


\section{KESIMPULAN}

Dalam artikel ini, penulis menyampaiakan beberapa kesimpulan sederhana. Secara garis besar, penulis memusatkan perhatian pada diskusi insekuritas pangan, berupa kelaparan yang dianggap memiliki beberapa limitasi pandangan. Narasi ketahanan pangan dan kedaulatan pangan saling berkontestasi satu sama lain. Meski begitu, keduanya bukanlah sebagai konsep oposisional, melainkan sebagai konsep yang saling terkait khususnya mencakup pada upaya mengatasi kelaparan yang meliputi pada akses, distribusi, keamanan, dan kesetaraan. Sementara itu pendekatan keamanan nasional berdasarkan neorealis maupun keamanan manusia berdasarkan Mazhab Kopenhagen memiliki perbedaan signifikan. Akan tetapi keduanya bermasalah dalam memposisikan kelaparan sebagai isu keamanan. Realisme yang bersandar pada state-centric menempatkan penanganan kelaparan adalah konsentrasi aktivitas pemerintah dalam memastikan kepentingan nasional, sehingga kebijakan yang ada ada pada bagaimana ketersediaan makanan dapat tercukupi atau surplus. Sementara itu, perspektif keamanan manusia melihat isu kelaparan yang dihadapi oleh manusia sehingga diperlukan proses sekuritisasi yang dijalankankan oleh agen sekuritisasi. Terlihat di sini bahwa tindakan mengatasi persoalan mendasar hanya menjadi tanggung-jawab di tingkat elit, sementara suara kepentingan individu yang mengalami kelaparan terabaikan.

Dengan demikian, pendekatan keamanan kritis muncul dalam menengahi beragam limitasi di atas. Perspektif ini manawarkan bahwa isu kelaparan harus mengalami pembingkaian ulang baik secara definisi maupun dalam aplikasi kebijakan sebagaimana masalah keamanan ini sebagai masalah structural. Kata kunci dari perspektif ini ialah memosisikan isu kelaparan harus dipahami sebagai proyek emansipasi. Seperti yang disampaikan oleh Booth, "emancipation seeks the securing of people from those oppressions that stop them carrying out what they would freely choose to do, compatible with the freedom of others (2007, p. 112)." Jadi, kelaparan atau orang yang tidak menerima kecukupan sumber makanan merupakan tragedi penindasan yang paling menyedihkan bagi sejarah manusia. Dalam sudut pandang ini, ketahanan pangan harus dibingkai ulang dalam 
konteks mengamankan atau melindungi populasi yang rentan dari kekerasan structural kelaparan.

Alternatif paradigma baru mengenai ketahanan pangan melalui perspektif keamanan kritis sebagai cara untuk memberikan hak keistimewaan bagi seluruh orang tanpa eksepsi. Dengan begitu fokus utama kebijakan ketahanan pangan, adalah manusia yang mengalami atau rentan dari kelaparan. Pembingkaian ini juga menempatkan tanggung jawab kepada para aktor atau agen institusional dan sistemik dari lembaga negara maupun internasional. Dengan demikian, cara kolaboratif semacam itu adalah upaya menjalankan prinsip-prinsip keamanan emansipatoris.

\section{Komparasi Perspektif}

\begin{tabular}{|c|c|c|c|c|c|}
\hline Karakteristik & $\begin{array}{c}\text { Ketahanan } \\
\text { Pangan/Liberalisme }\end{array}$ & $\begin{array}{c}\text { Kedaulatan } \\
\text { Pangan/Strukturalisme }\end{array}$ & $\begin{array}{c}\text { Keamanan } \\
\text { Nasional/Realisme }\end{array}$ & $\begin{array}{c}\text { Keamanan } \\
\text { Manusia/Mazhab } \\
\text { Kopenhagen }\end{array}$ & $\begin{array}{l}\text { Keamanan } \\
\text { Kritis }\end{array}$ \\
\hline Unit Analisis & $\begin{array}{l}\text { Aktor Negara dan } \\
\text { Non-Negara }\end{array}$ & $\begin{array}{l}\text { Aktor lebih spesifik } \\
\text { dalam struktur global, } \\
\text { menyangkut negara [inti } \\
\text { dan pingggiran], } \\
\text { masyarakat sipil, } \\
\text { korporasi dan peasent }\end{array}$ & Negara & $\begin{array}{l}\text { Individu dan } \\
\text { Negara }\end{array}$ & $\begin{array}{l}\text { Individu yang } \\
\text { menghadapi } \\
\text { kelaparan }\end{array}$ \\
\hline $\begin{array}{l}\text { Pandangan } \\
\text { Terhadap } \\
\text { Kelaparan }\end{array}$ & $\begin{array}{l}\text { Ketidaktersediaan } \\
\text { akses makanan dan } \\
\text { kesusaian harga }\end{array}$ & $\begin{array}{l}\text { Ketidakadilan pangan } \\
\text { dan kemiskinan sebagai } \\
\text { penyebab kelaparan } \\
\text { akibat rezim kapitalisme } \\
\text { global }\end{array}$ & $\begin{array}{l}\text { Ketidakmampunan } \\
\text { negara dalam } \\
\text { menggapai } \\
\text { kepentingan } \\
\text { esensial di tengah } \\
\text { sistem anarki }\end{array}$ & $\begin{array}{lr}\text { Kelaparan } & \text { adalah } \\
\text { objek } & \text { referen } \\
\text { dalam keamanan }\end{array}$ & $\begin{array}{l}\text { Kelaparan } \\
\text { bukanlah } \\
\text { proses } \\
\text { alamiah, } \\
\text { melainkan } \\
\text { persoalan } \\
\text { structural. } \\
\text { Sehingga fokus } \\
\text { penanganannya } \\
\text { adalah } \\
\text { mengamankan } \\
\text { populasi yang } \\
\text { rentan dari } \\
\text { kekerasan } \\
\text { structural } \\
\text { kelaparan }\end{array}$ \\
\hline Instrumen & $\begin{array}{l}\text { Rezim pangan global } \\
\text { dan bantuan } \\
\text { internasional }\end{array}$ & $\begin{array}{l}\text { Negara harus } \\
\text { memastikan bahwa } \\
\text { kehadiran pasar pangan } \\
\text { domestik dan global } \\
\text { adalah instrument } \\
\text { melayani } \\
\text { kepentingannya, dengan } \\
\text { tindakan-tindakan } \\
\text { proteksionis }\end{array}$ & $\begin{array}{l}\text { Reforma agraria, } \\
\text { prioritas kebijakan } \\
\text { nasional harus } \\
\text { melindungi sumber } \\
\text { pangan secara } \\
\text { keberlanjutan, } \\
\text { meniadakan celah- } \\
\text { celah ketidakadilan } \\
\text { sistem ekonomi } \\
\text { pangan global }\end{array}$ & $\begin{array}{l}\text { Sekuritisasi } \\
\text { berbasis } \\
\text { instrument negara }\end{array}$ & $\begin{array}{l}\text { Membingkai } \\
\text { isu kelaparan } \\
\text { sebagai } \\
\text { masalah } \\
\text { structural, } \\
\text { Sehingga fokus } \\
\text { penanganannya } \\
\text { adalah } \\
\text { mengamankan } \\
\text { populasi yang } \\
\text { rentan dari } \\
\text { kekerasan } \\
\text { struktural }\end{array}$ \\
\hline
\end{tabular}




\begin{tabular}{|l|l|l|l|l|l|}
\hline & & & & & kelaparan \\
\hline
\end{tabular}

\section{DAFTAR PUSTAKA}

Balaam, D. N., \& Veseth, M. (2014). Introduction to International Political Economy. New York: Pearson.

Bello, W. (1999). Dark Victory: The United States, Structural Adjustment and Global Poverty. London: Pluto Press.

Bernstein, H. (2014). Food Sovereignty via the 'Peasant' Way: A Sceptical View. The Journal of Peasent Studies, 41 (6), 1031-1063.

Boerma, A. H. (1975). Political Will and The World Food Problem. New Delhi: Food and Agriculture Organization of the United Nations.

Booth, K. (1999). Security and Emancipation. Review of International Studies, 35 (3), 313-326.

Booth, K. (2007). Theory of World Security. Cambridge: Cambridge University Press.

Campesina, V. (2001). Our World Is Not for Sale: Declaration of Food Sovereignty. Retrieved January 24, 2018, from www.voiceoftheturtle.org

Campesina, V. (1996). The Right to Produce and Access to Land. Retrieved January 22, 2018, from http://www.acordinternational.org/silo/files/decfoodsov1996.pdf

Clapp, J. (2006). WTO Agriculture Negotiations: Implications for the Global South. Third World Quarterly, 27 (4), 563-577.

Clapp, J., \& Cohen, M. J. (2009). The Food Crisis and Global Governance. In J. Clapp, \& M. J. Cohen (Eds.), The Global Food Crisis: Governance Challanges and Opportunities. Ontario: Wilfred Laurier Press.

Clapp, J., \& Cohen, M. J. (2009). The Food Crisis and Global Governance. In J. Clapp, M. J. Cohen, J. Clapp, \& M. J. Cohen (Eds.), The Global Food Crisis: Governance Challanges and Opportunities. Ontario: Wilfred Laurier Press.

Cox, R. W. (1981). Social Forces, States, and World Orders: Beyond International Relations Theory. Millenium: Journal of International Studies, 10 (2), 126-155.

Death, C. (2011). Food Security: Issues and Trends in International Politics. IBERS: Knowledge-Based Innovations, 4, 32-37.

Dickson, A. (1997). Development and International Relations: A Critical Introduction. Cambridge: Polity Press.

Duffield, M., \& Waddell, N. (2006). Securing Humans in a Dangerous World. International Politics, 43 (1), 1-23. 
FAO. (2006, June). Food Security. Retrieved January 5, 2018, from https://goo.gl/A6ccbH FAO. (1996, November 13-17). Rome Declaration on World Food Security. Retrieved from World Food Summit: http://www.fao.org/3/w3613e/w3613e00.htm

Gao, S. (2011). Discussion on Issues of Food Security Based on Basic Domestic SelfSuffiency. Asian Social Science, 6 (11), 42-48.

Gill, G. J., Farrington, J., Anderson, E., Luttrell, C., Conway, T., Saxena, N., et al. (2003, December). Food Security and the Millennium Development Goal on Hunger in Asia. Overseas Development Institute.

Grayson, K. (2008). Human Security as Power/Knowledge: The Biopolitics of a Definitional Debate. Cambridge Review of International Affairs, 21 (3), 383-401.

IAASTD. (2009). Global Report. Washington DC: Island Press.

J.R. Tarrant. (1981). Food as a Weapon? The Embargo on Grain Trade Between USA and USSR. Applied Geography, 1 (4), 273-286.

Jarosz, L. (2014). Comparing Food Security and Food Sovereinty Discources. Dialogues in Human Geography, 4 (2), 168-181.

Jones, R. W. (1999). Security, Strategy and Critical Theory. Colorado: Lynne Rienner Publishers.

Jones, R. W. (1999). Security, Strategy, and Critical Theory. Denver: Lynne Rienner Publishers.

Keen, D. (2008). Complex Emergencies. Cambridge: Polity Press.

Kunjoro, I. A., Jamil, S., \& Mathur, A. (2013). Food. In M. Caballero-Anthony, \& A. D. Cook, Non-Traditional Security in Asia: Issues, Challanges and Framework for Action. Singapore: ISEAS.

Maxwell, S. (2001). The Evolution of Thinking About Food Security. In S. Devereux, \& S. Maxwell, Food Security in Sub-Saharan Africa. London: ITDG Publishing.

Morgan, D. (1979). Merchants of Grain. New York: Penguin Books.

Morgenthau, H. J. (1948). Politics Among Nations: The Struggle for Power and Peace. Toronto: Ryerson Press.

Patel, R. (2009). What does food sovereignty look like? The Journal of Peasant Studies, 36 (3), 668-706.

Rajaonarison, H. M. (2014). Food and Human Security in Sub-Saharan Africa. Procedia Environmental Sciences, 20 (1), 377-385.

Redclift, M. (1987). Sustainable Development: Exploring the Contradictions. London: Routledge.

Riley, B. (2017). The Political History of American Food Aid: An Uneasy Benevolence. New York: Oxford University Press.

Sen, A. (1981). Poverty and Famine: An Essay on Entitlement and Deprivation. Oxford: Clarendon Press.

Sen, A. (1980). Famines. World Development, 8 (9), 613-621.

Sen, A. (1981). Ingredients of Famine Analysis: Availability and Entitlements. The Quarterly Journal of Economics, 96 (3), 433-464. 
Shaw, D. J. (2007). World Food Security: A History Since 1945. Basingstoke: Palgrave Macmillan.

Shepherd, B. (2012). Thinking Critically About Food Security. Security Dialogue, 43 (3), 195-212.

Smith, M., Pointing, J., \& Maxwell, S. (1993). Household Food Security: Concepts and Definitions. Road Brighton: Institute of Development Studies.

Smith, M., Pointing, J., \& Maxwell, S. (1993). Household Food Security: Concepts and Definitions: An Annotated Bibliography. Brighton: Institute of Development Studies.

UNDP. (1994). Human Development Report 1994. Oxford: Oxford Univesity Press.

UNICEF. (2006). Progress for Children: A Report Card on Nutrition. New York: UNICEF.

Uvin, P. (1994). The International Organisation of Hunger. London: Kegan Paul International.

Via Campesina. (1996). The Right to Produce and Access to Land. Retrieved January 22, 2018, from http://www.acordinternational.org/silo/files/decfoodsov1996.pdf

Waltz, K. (1979). Theory of International Politics. Reading: Addison-Wesley.

WFP. (2021, Januari 22). Zero Hunger. Retrieved Januari 22, 2021, from https://www.wfp.org/zero-hunger

Wisner, B., Weiner, D., \& O'Keefe, P. (1982). Hunger: A Polemical Review. Antipode, 14 (3), 1-16.

Wittman, H., Desmarais, A., \& Wiebe, N. (2010). The Origins \& Potential of Food Sovereignty. In H. Wittman, A. Desmarais, \& N. Wiebe, Food sovereignty: Reconnecting food, nature and community (pp. 1-14). Oakland: Food First.

World Bank. (1986). Poverty and Hunger: Issues and Options for Food Security in Developing Countries. Washington DC: World Bank. 